\title{
The alternatively initiated c-Myc proteins differentially regulate transcription through a noncanonical DNA-binding site
}

\author{
Stephen R. Hann, ${ }^{1,3}$ Mrinalini Dixit, ${ }^{1}$ Rosalie C. Sears, ${ }^{1}$ and Linda Sealy ${ }^{1,2}$ \\ ${ }^{1}$ Department of Cell Biology, ${ }^{2}$ Department of Molecular Physiology and Biophysics, Vanderbilt University, School \\ of Medicine, Nashville, Tennessee, 37232-2175 USA
}

The myc proto-oncogene family has been implicated in multiple cellular processes, including proliferation, differentiation, and apoptosis. The Myc proteins, as heterodimers with Max protein, have been shown to function as activators of transcription through an E-box DNA-binding element, CACGTG. We have now found that the c-Myc proteins regulate transcription through another, noncanonical, DNA sequence. The non-AUG-initiated form of the c-Myc protein, c-Myc 1, strongly and specifically activates transcription of the C/EBP sequences within the EFII enhancer element of the Rous sarcoma virus long terminal repeat. In contrast, comparable amounts of the AUG-initiated form, c-Myc 2, fail to significantly affect enhancer activity. However, both c-Myc proteins trans-activate the CACGTG sequence comparably. In addition, Myc/Max heterodimers, but not Max homodimers, bind to the EFII enhancer sequence in vitro. Finally, c-Myc 1 overexpression, but not c-Myc 2 overexpression, significantly inhibits cell growth. These results reveal new transcriptional activities for the Myc proteins and demonstrate that the different forms of the Myc protein are functionally distinct. These results also suggest an interplay between two different growth regulatory transcription factor families.

[Key Words: c-myc; C/EBP; non-AUG initiation; trans-activation; growth inhibition]

Received May 11, 1994; revised version accepted August 30, 1994.

Numerous reports have demonstrated a fundamental and diverse role for the c-myc gene in cellular events, including proliferation, differentiation, and apoptosis (Cole 1986; Askew et al. 1991; Spencer and Groudine 1991; Evan et al. 1992). The control that c-myc exerts over normal growth regulation is illustrated by the many types of tumors that are associated with an alteration of the c-myc locus in a variety of species, including humans (Cole 1986; Spencer and Groudine 1991). Although little is known about the molecular basis of how the Myc proteins influence these varied cellular events, high-level Myc expression results in the repression or activation of several genes (Luscher and Eisenman 1990). As a heterodimer with the Max protein (Blackwood and Eisenman 1991; Prendergast et al. 1991), Myc protein binds to the E-box sequence, CACGTG, termed the EMS (E box myc site) sequence (Blackwell et al. 1990; Prendergast and Ziff 1991). Both Myc/Max heterodimers and unphosphorylated Max homodimers have been found to bind to the CACGTG sequence (Blackwood and Eisenman 1991; Berberich and Cole 1992; Kato et al 1992), as have the related transcription factors, USF (Gregor et al. 1990), TFEB (Carr and Sharp 1990), TFE3 (Beckmann et al.

${ }^{3}$ Corresponding author.
1990), and AP-4 (Hu et al. 1990). Using an artificial target sequence containing the EMS site, it has been shown that c-Myc protein activates transcription in mammalian cells and yeast, albeit modestly, whereas Max represses transcription (Kretzner et al. 1992; Amin et al. 1993). Recently, specific genes containing EMS sequences have been found to be activated by c-Myc protein, including the p53 gene (Reisman et al. 1993), the embryonically expressed gene ECA39 (Benvenisty et al. 1992) and the ornithine decarboxylase gene (BelloFernandez et al. 1993).

The structural features of $\mathrm{c}-\mathrm{Myc}$ protein that appear to be important for sequence-specific DNA binding and Max binding are contained within the carboxy-terminal region of the protein. These features consist of two protein dimerization motifs, a helix-loop-helix (HLH) domain and a leucine zipper (LZ) domain, and a basic region (b) necessary for DNA binding once dimerization has occurred (Davis et al. 1990; Voronova and Baltimore 1990). The significance of having two dimerization motifs within the Myc proteins is not known; however, the b, HLH, and LZ regions have all been shown to be essential for biological activity (Stone et al. 1987; Dang et al. 1989; Amati et al. 1993). Although the carboxyl terminus of Myc is necessary and sufficient for sequencespecific DNA binding and dimerization, the amino-ter- 
minal domain appears to be necessary for trans-activation (Kato et al. 1990; Kretzner et al. 1992).

A distinctive feature of the myc gene is that it encodes two amino-terminally distinct proteins. Two translational forms of the Myc protein exist for all species of c-Myc examined thus far (Hann and Eisenman 1984; Hann et al. 1988), as well as for N-Myc (Ramsay et al. 1986) and L-Myc proteins (Dosaka-Akita et al. 1991). The c-Myc 1 protein arises from an upstream non-AUG translational start site and thus contains an amino-terminal extension of 14 amino acids compared with c-Myc 2 protein (Hann et al. 1988). There are several lines of evidence to suggest a functional significance for $\mathrm{c}-\mathrm{Myc} 1$ protein in cell growth and tumorigenesis. The synthesis of c-Myc 1 is disrupted in many human Burkitt's lymphomas and avian bursal lymphomas (Hann and Eisenman 1984; Hann et al. 1988; G. Spotts and S. Hann, unpubl.). In addition, these two forms of c-Myc protein are differentially synthesized during cell growth. At high cell density the normally inefficient non-AUG initiation event is activated, resulting in a predominance of the c-Myc 1 protein (Hann et al. 1992). These observations suggest a growth inhibitory role for c-Myc 1 protein, whereas c-Myc 2 and $\mathrm{v}-\mathrm{Myc}$ proteins have long been shown to be growth stimulatory (Cole 1986; Spencer and Groudine 1991).

In this report we describe a functional difference for the two forms of the c-Myc protein in the control of transcription and growth. Through an investigation of factors that specifically bind and influence the activity of enhancer elements within the Rous sarcoma virus (RSV) long terminal repeat (LTR), we examined the activity of Myc proteins on the transcriptional activation by a specific enhancer element, EFII. The EFII cis element (Sealy and Chalkley 1987; Sears and Sealy 1992/ consists of two nearly direct repeat sequence elements that do not contain EMS-binding sites. The upstream 15 -bp repeat contains a consensus binding site $\left(\mathrm{T}^{\mathrm{T}} /{ }_{\mathrm{G}} \mathrm{NNG} \mathrm{C} / \mathrm{AA}_{\mathrm{T}}^{\mathrm{T}} / \mathrm{G}\right)$ for the CCAAT/enhancer-binding protein (C/EBP) family of transcription factors, whereas the downstream 13-bp repeat contains a related, but lower affinity C/EBP site (Sears and Sealy 1992). The C/EBP family consists of several related transcription factors that appear to be important in the regulation of growth and differentiation (Cao et al. 1991; Umek et al. 1991). The EFII element has been shown to be a binding site for C/EBP (NFIL-6) in nuclear extracts (Wegner et al. 1992; Sears and Sealy 1994), as well as purified C/EBP (Ryden and Beemon 1989 ), and two recombinant fusion proteins, $\beta$-galactosidase-Ig/EBP-1 (C/EBP $\tau)$ (Roman et al. 1990) and a1/EBPGST (Bowers and Ruddell 1993) in vitro. In addition, the $\mathrm{C} / \mathrm{EBP} \beta$ protein has been shown to trans-activate the EFII enhancer element in pituitary cells (Wegner et al. 1992). Herein, we demonstrate that the c-Myc proteins also regulate the transcriptional activity of the EFI enhancer element through C/EBP-binding sequences and that the alternative forms of the Myc protein differentially regulate EFII-mediated transcription. We also show that Myc/Max heterodimers, but not Max homodimers, can bind the EFII enhancer sequence in vitro. In addition, the two alternatively initiated forms of c-Myc have differential effects on cell growth.

\section{Results \\ Differential trans-activation of the EFII enhancer element by two translational forms of $c-M y c$}

To examine the ability of the c-Myc proteins to regulate transcription, the overexpression of the c-Myc proteins in mammalian cells was required. Also, because there are at least two c-Myc proteins differing at their amino termini, it is possibile that the different forms have different trans-activation abilities. To allow for selective synthesis, we performed site-directed mutagenesis as illustrated in Figure 1A on the murine c-myc cDNA as we had done previously with the human c-myc 1 cDNA (Hann et al. 1988). The AUG-initiated c-Myc 1 protein synthesized from this optimized cDNA is identical with the CUG-initiated protein, because a methionine is used to initiate at both non-AUG and AUG start codons (Donahue et al. 1988; Peabody 1989). To distinguish the exogenous overexpressed murine c-Myc proteins from the same or similar-sized endogenous c-Myc proteins of murine, human, or closely related mammalian species, we also changed the penultimate carboxy-terminal amino acid in the murine c-myc cDNA from a glycine to an arginine residue, as found in avian c-Myc proteins. This enabled specific recognition of the exogenous c-Myc proteins with a peptide antibody directed against the carboxyl 12 amino acids of the avian c-Myc protein (antiav-myc $12 \mathrm{C}$ ). The altered cDNAs were then placed into a vector for in vitro transcription and translation and for overexpression in eukaryotic cells. In vitro translation of RNA from these constructs yielded the predicted murine c-Myc 1 or 2 proteins, as illustrated in Figure 1B. COS cells stably expressing the exogenous C-Myc 1 or 2 proteins were then generated for trans-activation assays by transfection with the cytomegalovirus (CMV)-Myc 1 or CMV-Myc 2 vectors. The expression of the exogenous $\mathrm{c}-\mathrm{Myc}$ proteins was quantitated by immunoprecipitation using the anti-av-myc $12 \mathrm{C}$ serum. As shown in Figure 1C, the transfected COS cells synthesized either the c-Myc 1 or 2 protein in comparable amounts. The antiav-myc $12 \mathrm{C}$ serum did not recognize the endogenous c-Myc proteins (Fig. 1A, control lane). The appearance of the c-Myc 1 and 2 proteins as doublets in vivo was most likely the result of post-translational modification. Similar modified forms of c-Myc 1 and 2 have been observed previously in several different cell types (Spotts and Hann 1990).

Having the capability to selectively synthesize comparable amounts of c-Myc 1 or 2 protein in the COS cells allowed us to examine the ability of each of the c-Myc proteins to regulate transcription through the RSV LTR enhancer elements using standard trans-activation assays. We initially used the chloramphenical acetyltransferase (CAT) reporter plasmid, ([EFII $\left.]_{6} \mathrm{CAT}\right)$, which contains minimal LTR promoter sequences (e-CAT), linked to six copies of the EFII sequence (Sears and Sealy 1992). 
A

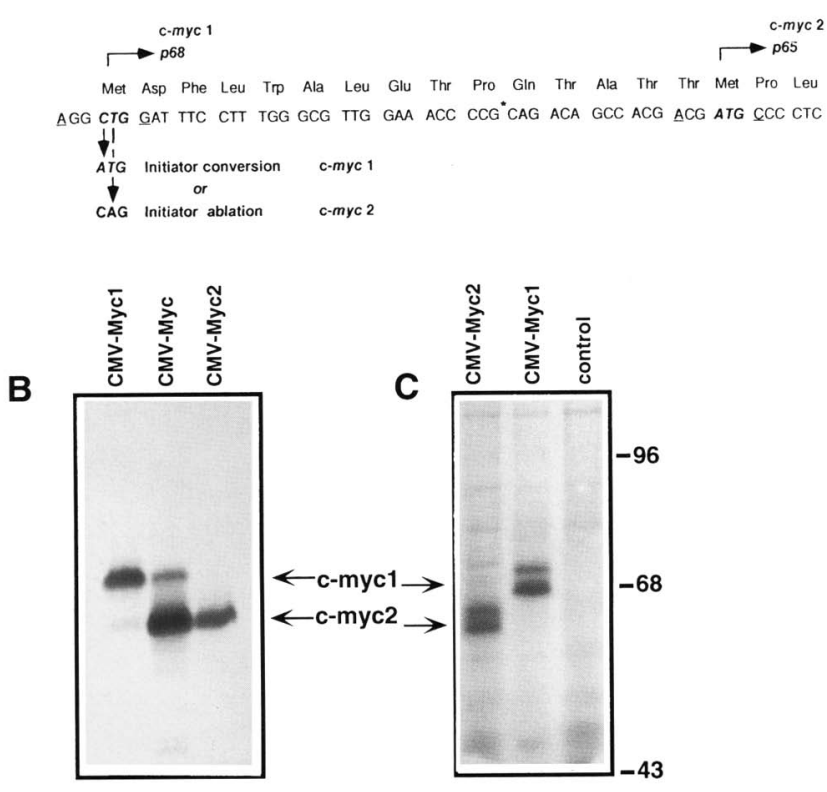

Figure 1. Selective synthesis of c-Myc 1 or 2 protein in vitro or in vivo. $(A)$ Site-directed mutagenesis of the initiator codon for the murine c-Myc 1 protein was performed as described in Materials and methods. The indicated alterations were designed to allow for optimal synthesis of c-Myc 1 or ablation of c-Myc 1 synthesis. $(B)$ RNAs synthesized from the site-directed mutated cDNAs described above and from the unaltered myc cDNA were translated in a reticulocyte lysate, and the synthesized proteins were then immunoprecipitated with anti-av-myc $12 \mathrm{C}$ as described in Materials and methods. The affinity-purified rabbit avian-specific c-myc peptide antibody (anti-av-myc 12C) was used to detect the exogenous modified murine Myc proteins expressed by the CMV-Myc vectors. $(C)$ The c-Myc proteins were immunoprecipitated with anti-av-myc $12 \mathrm{C}$ from stable COS cells that had been transfected with either CMV-Myc 1 or CMV-Myc 2 expression vectors. COS- 1 cells stably overexpressing the c-Myc proteins were generated as described in Materials and methods. Untransfected COS cells (control) or transfected cells were labeled with $\left[{ }^{35} S\right]$ methionine for $20 \mathrm{~min}$ and the cell lysates were equalized for TCA-precipitable counts as described in Materials and methods.

The relative position of the EFII element in the RSV LTR enhancer and sequence of the EFII element is illustrated in Figure 2A. A SV40- $\beta$-galactosidase expression vector was cotransfected to standardize for transfection efficiency. The $[\mathrm{EFII}]_{6} \mathrm{CAT}$ reporter gene and the SV40- $\beta$ galactosidase expression vector were cotransfected into the COS cells stably overexpressing either c-Myc 1 or 2 protein or into control COS cells. As shown in Figure 2B, EFII-mediated transcription was dramatically increased in the COS cells overexpressing c-Myc 1 protein. The EFII cis element was $\sim 40$-fold (range 10 - to 40 -fold) more active in these cells compared with control cells. In contrast, no effect on EFII-driven transcription was detected in cells overexpressing comparable amounts of c-Myc 2 protein. Next, we determined whether the c-Myc pro- teins could trans-activate the EFIII element, another cisacting sequence found in the RSV LTR. This element has a CArG DNA sequence motif (Fig. 2A), which is a binding site for the serum response factor (Boulden and Sealy 1992). The COS cells were transfected with an e-CAT reporter construct carrying five copies of the EFIII cis element ([EFIII $]_{5}$ CAT) (Boulden and Sealy 1992). Figure $2 \mathrm{~B}$ reveals that there were no significant increases in EFIII-dependent transcription in either the c-Myc 1- or 2-overexpressing COS cells relative to the control cells.

To determine whether the C/EBP-binding sequences were necessary for trans-activation, c-Myc 1-overexpressing COS cells were transfected with an e-CAT construct, which contained two copies of an EFII mutant element ([EFII5'/3'mutant $]_{2}$ CAT) lacking C/EBP sites (Sears and Sealy 1992). As shown in Figure 2C, c-Myc 1 protein failed to trans-activate the mutant EFII element. Also, the e-CAT construct, containing only basal LTR promoter sequences, was unaffected by c-Myc 1 overexpression (Fig. $2 \mathrm{C}$ ). In contrast, the c-Myc 1 protein was able to trans-activate one copy of the EFII enhancer approximately ninefold (Fig. 2C). A reporter construct, $\left[\text { EFII5 }^{\prime}\right]_{4}$ CAT, containing tandem repeats of just the $5^{\prime}$ high affinity C/EBP-binding site (Fig. 2A) was also transactivated by the c-Myc 1 protein (data not shown). These data suggest that the C/EBP sequences are necessary for trans-activation and that the higher affinity $5^{\prime} \mathrm{C} / \mathrm{EBP}$ sequence is sufficient. In support of this observation, trans-activation analysis of the related NF-IL6 (C/EBP $\beta$ ) sequence from the IL 6 promoter by c-Myc 1 overexpression revealed that an e-CAT construct containing two copies of the NF-IL6 oligonucleotide was trans-activated efficiently (data not shown).

To determine whether the c-Myc 1 protein could trans-activate the EFII enhancer sequence in its natural context within the RSV LTR, trans-activation assays using the c-Myc 1-or 2-overexpressing COS cell lines were performed with the Schmidt Ruppin A (SRA)-CAT construct containing the entire RSV LTR /Boulden and Sealy 1990). As shown in Figure 2D, the c-Myc 1 protein stimulated LTR enhancer-driven transcription approximately sixfold relative to control cells, whereas c-Myc 2 overexpression had no effect on LTR enhancer activity. Taken together, these results suggest that c-Myc 1 protein is a specific and potent activator of the EFII enhancer sequence of the RSV LTR.

To determine whether the c-Myc proteins also differentially trans-activate through the canonical EMS sequence, a CAT reporter construct containing four copies of the CACGTG sequence was transfected into the COS cells overexpressing the different forms of the c-Myc protein. Although the overexpression of c-Myc 2 had no effect on EFII-mediated transcription as shown in Figure 2 , both c-Myc 1 and 2 trans-activated the [EMS $]_{4}$ CAT reporter comparably (Fig. 3). In addition, a mutated c-Myc protein lacking the first 100 amino acids of the amino terminus failed to trans-activate the EMS or EFII sequence (data not shown), as was shown previously for the EMS sequence (Kretzner et al. 1992). Therefore, these results demonstrate that the overexpressed c-Myc 2 pro- 
Figure 2. Trans-activation of EFII enhancer sequences by the $\mathrm{c}-\mathrm{Myc} 1$ protein in COS cells. $(A)$ The RSV LTR enhancer plus basal promoter $(\mathrm{e}-)$ is diagramed to illustrate the relative position of the enhancer elements EFII and EFIII. The sequences of the enhancer elements from the reporter constructs that were used in the trans-activation assay are also shown. The BamHI linker sequences disrupting the EFII repeat sequences in the mutant EFII5'3' oligonucleotide are boxed. The CArG sequence (senum response factor-binding site) is underlined in the EFIII sequence. $(B)$ Control COS cells (con) or stable COS cells overexpressing c-Myc 1 or 2 described in Fig. 1C were transfected with $10 \mu \mathrm{g}$ of [EFII] 6 CAT or $[\mathrm{EFII}]_{5} \mathrm{CAT}$ and $5 \mu \mathrm{g}$ of SV40- $\beta$-galactosidase by calcium phosphate coprecipitation. The $\beta$-galactosidase and CAT activities were determined after harvesting the cells $48 \mathrm{hr}$ later. The CAT activities relative to the control cells are shown below the lanes. (C) Control cells or stable COS cells overexpressing c-Myc 1 were transfected with 10 $\mu \mathrm{g}$ of the indicated CAT constructs and $5 \mu \mathrm{g}$ of SV40- $\beta$-galactosidase, and the relative CAT activities were determined as described above. $(D)$ Control COS cells or stable COS cells overexpressing c-Myc 1 or 2 were transfected with $10 \mu \mathrm{g}$ of SRA-CAT (RSV LTR enhancer) and $5 \mu \mathrm{g}$ of SV40- $\beta$ galactosidase, and the relative CAT activities were determined as described above.

\section{A}

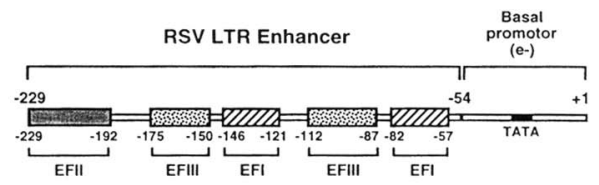

EFI: AATGTAGTCTTATGCAATACTCTTGTAGTCTTGCAACA EFll 5: GTAGTCTTATGCAA

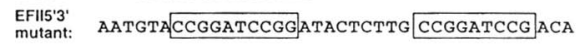

EFIII: CGATCGTGCCTTATTAGGAGGCAAC

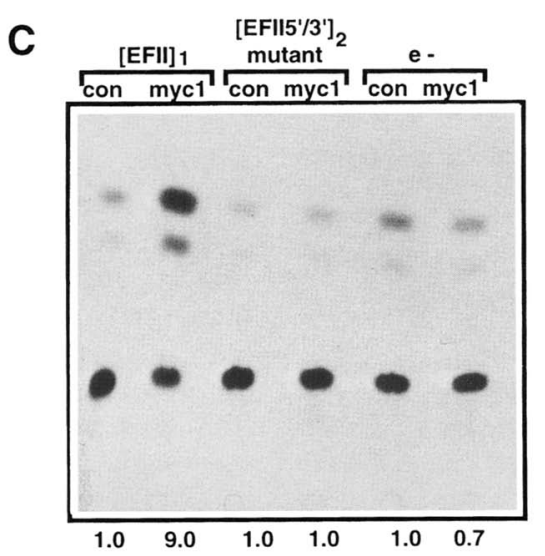

B
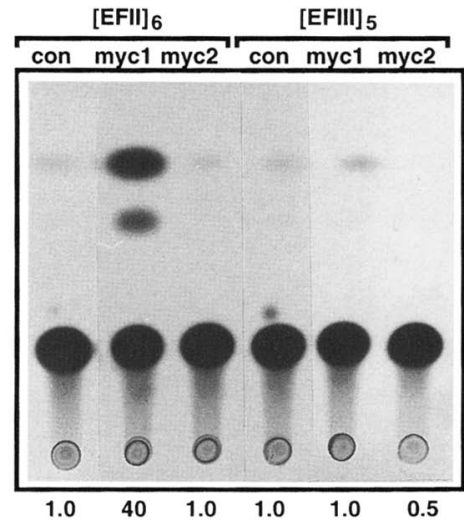

D

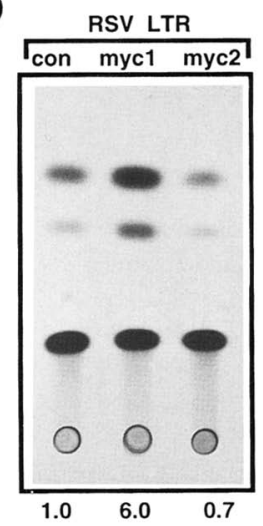

tein is functionally active and capable of trans-activation.

Because continuous overexpression of Myc proteins may cause deleterious or aberrant effects on cellular processes, we determined whether transient expression of the $\mathrm{c}-\mathrm{Myc} 1$ protein could also trans-activate the EFII enhancer element. The $[\mathrm{EFII}]_{6} \mathrm{CAT}$ and SV40- $\beta$-galactosidase constructs were transiently cotransfected with either the CMV-Myc 1, the CMV-Myc 2 or control vector into COS cells. Again, to confirm that the Myc proteins were expressed after $48 \mathrm{hr}$ following transfection, the c-Myc proteins were immunoprecipitated with antiav-myc $12 \mathrm{C}$ serum from duplicate plates of COS cells. As shown in Figure 4A, the exogenous c-Myc 1 and 2 proteins were expressed at comparable levels. The relative levels of EFII-dependent transcription were then determined. Figure 4B shows that COS cells overexpressing the c-Myc 1 protein had $\sim 16$-fold higher levels of EFII activity than control cells or cells expressing c-Myc 2. Overexpression of the CMV-Myc vector that allows normal synthesis of the c-Myc proteins was also examined with the $[\mathrm{EFII}]_{6} \mathrm{CAT}$ construct. Even though this construct yields higher levels of c-Myc 2 than c-Myc 1, significant trans-activation was observed (data not shown). To determine whether the level of c-Myc 1 expression correlated with the magnitude of EFII trans-activation,

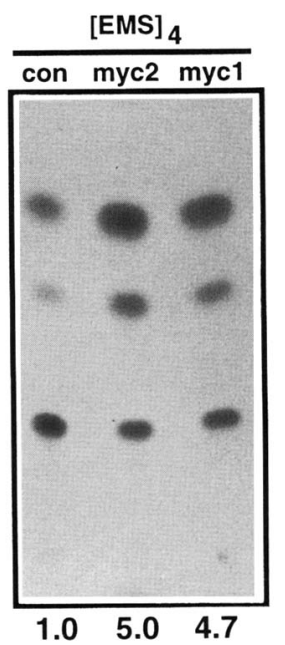

Figure 3. Trans-activation of the canonical EMS sequence by overexpression of the c-Myc proteins. Control COS cells (con) or stable COS cells overexpressing c-Myc 1 or 2 described in Fig. IC were transfected with $10 \mu \mathrm{g}$ of [EMS ${ }_{4} \mathrm{CAT}$ and $5 \mu \mathrm{g}$ of SV40$\beta$-galactosidase by calcium phosphate coprecipitation. The $\beta$-galactosidase and CAT activities were determined after harvesting the cells $48 \mathrm{hr}$ later. The CAT activities relative to the control cells are shown below the lanes. 

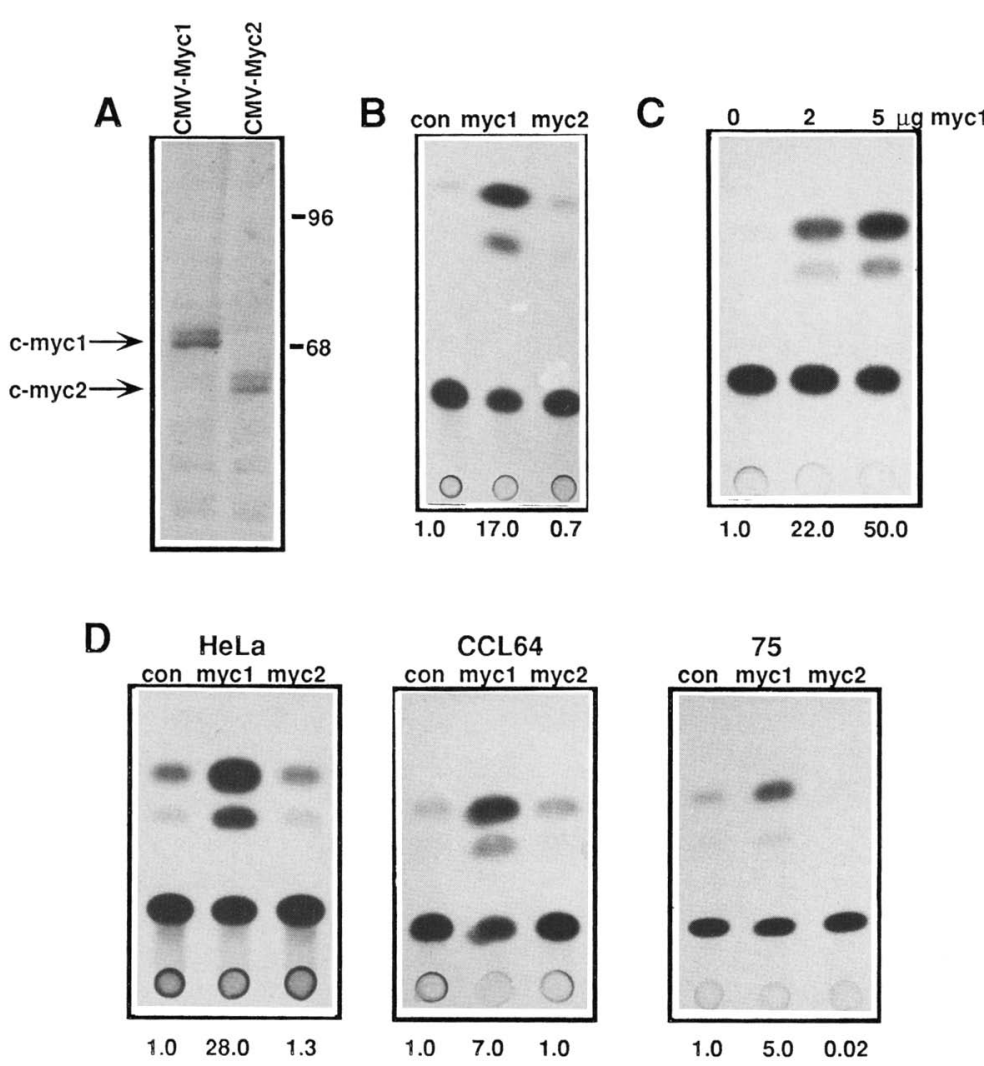

Figure 4. Trans-activation of the EFII enhancer sequences by transient overexpression of the c-Myc 1 protein. $(A) \mathrm{COS}$ cells were cotransfected with $10 \mu \mathrm{g}$ of $[\mathrm{EFII}]_{6} \mathrm{CAT}, 5 \mu \mathrm{g}$ of SV40- $\beta$-galactosidase, and 10 $\mu \mathrm{g}$ of either the CMV-Myc 1 or CMV-Myc 2 vectors. After $48 \mathrm{hr}$ in culture, the cells were labeled with $\left[{ }^{35} \mathrm{~S}\right]$ methionine for $20 \mathrm{~min}$, lysates were equalized for TCA-precipitable counts, and c-Myc proteins were immunoprecipitated with anti-av-myc $12 \mathrm{C}$ as described in Fig. 1C. $(B)$ Duplicate dishes of the cotransfected COS cells described above that overexpress the c-Myc 1 or 2 proteins and cells cotransfected with the control CMV vector were harvested after $48 \mathrm{hr}$ in culture, and the $\beta$-galactosidase and CAT activities were determined as described in Fig. 2B. The CAT activities relative to the control cells are shown below the lanes. $(C)$ COS cells were cotransfected with $10 \mu \mathrm{g}$ of [EFII $]_{6} \mathrm{CAT}, 5 \mu \mathrm{g}$ of SV40- $\beta$-galactosidase, and 0,2 , or $5 \mu \mathrm{g}$ of the CMV-Myc 1 vector. The relative CAT activities were determined as described in Fig. 2B. $(D)$ The indicated cell lines were cotransfected with $10 \mu \mathrm{g}$ of $[\mathrm{EFII}]_{6} \mathrm{CAT}, 5 \mu \mathrm{g}$ of SV40- $\beta$-galactosidase, and 10 $\mu \mathrm{g}$ of the CMV-Myc 1, CMV-Myc 2, or control CMV vector. After $48 \mathrm{hr}$ in culture, the $\beta$-galactosidase and CAT activities were determined as described in Fig. 2B. we cotransfected the $[\mathrm{EFII}]_{6} \mathrm{CAT}$ construct with different amounts of the CMV-Myc 1 vector. As shown in Figure $4 \mathrm{c}$, there was a proportionate increase in the activity of the EFII enhancer with an increased amount of CMVMyc 1 DNA. COS cells overexpressing c-Myc 1 protein also had higher levels of CAT mRNA compared with control cells as determined by RNase protection assays, and the relative increase in mRNA was comparable to the increase in CAT activity observed in parallel cells (data not shown).

To determine whether the ability of the c-Myc 1 protein to trans-activate the EFII enhancer element is cell type specific, we examined EFII enhancer activity after transient cotransfection of HeLa cells, a mink epithelial cell line (CCL64), or a human lung fibroblast cell line (75) with the CMV-Myc 1 or 2 vectors and the [EFII] ${ }_{6}$ CAT reporter construct. As shown in Figure 4D, the transient overexpression of C-Myc 1 protein stimulated EFII enhancer activity by 5 - to 28 -fold in all of the cell lines examined. As with the COS cells, c-Myc 2 protein had a minimal effect on EFII transcription in the HeLa and CCL64 cells; however, there was a significant repression of EFII-driven transcription by c-Myc 2 protein in the human fibroblast line 75 . This suggests that the ability of c-Myc 2 protein to repress transcription through EFII sequences may be dependent on the cell type, whereas c-Myc 1 trans-activation is not limited to specific cell types. In addition, we transiently cotransfected mouse NIH-3T3 fibroblast cells with an SV40-vMyc expression vector and with the $[\mathrm{EFII}]_{6} \mathrm{CAT}$ reporter gene or the $\left[\mathrm{EFII5}{ }^{\prime}\right]_{4} \mathrm{CAT}$ reporter construct. The EFIImediated transcription was repressed four- to fivefold by transient overexpression of MC29 $\mathrm{v}$-Myc protein in the NIH-3T3 cells (data not shown).

Myc/Max heterodimers, but not Max homodimers, bind to the EFII enhancer DNA sequence.

Because the c-Myc 1 protein appeared to be a potent trans-activator of the EFII enhancer element, we wanted to determine whether $\mathrm{c}-\mathrm{Myc}$ protein could bind to these sequences. To examine the abilities of Myc and/or Max to bind to the EFII enhancer sequence, we used the soluble, bacterially expressed murine Myc249 protein (the carboxy-terminal 249 amino acids) and the murine Max protein. These proteins have been used previously to examine the ability of Myc and Max to bind to the EMS site (Berberich and Cole 1992). Full-length Myc proteins could not be used because they are insoluble in vitro. Nuclear extracts containing c-Myc and Max proteins were also not used because these extracts have failed to show specific Myc/Max binding to the EMS sequence (Berberich and Cole 1992; Littlewood et al. 1992). The Myc249 and Max proteins both have amino-terminal polyhistidine tracts that allowed purification by chromatography on nickel-chelate columns. We first established that our purified preparations of Myc249 and Max proteins bind to the EMS site. Following dimerization, the individual proteins or Myc/Max protein mixtures were incubated with a radiolabeled 28-bp oligonucle- 
otide containing an "optimized" EMS site (Halazonetis and Kandil 1991|, and the binding was measured by an electrophoretic mobility shift assay (EMSA). In accordance with observations published previously (Berberich and Cole 1992; Kato et al. 1992), Figure 5A demonstrates that both Myc/Max heterodimers and Max homodimers bind well to the EMS sequence, although Myc249 protein, which does not form homodimers efficiently, does not bind.

The same purified protein preparations were then used to determine whether the Myc or Max proteins could bind to the EFII enhancer sequence. We used a 44-bp oligonucleotide containing the entire EFII enhancer element (Sears and Sealy 1992). As with the EMS oligonucleotide, the Myc249/Max protein mixture bound to the EFII oligonucleotide while the Myc249 protein failed to bind (Fig 5A). However, in contrast to efficient binding of Max homodimers to the EMS oligonucleotide, Max protein did not bind to the EFII enhancer oligonucleotide. These observations suggest that Myc binding to the EFII DNA sequence, as with the EMS sequence, requires Myc/Max heterodimerization. However, binding to the EFII sequence is unique in that Max homodimers cannot bind.

To confirm that Myc249 and Max proteins were present in the shifted EMS and EFII DNA complexes, we incubated the protein dimers with specific antibodies against the murine Myc (anti-mu-myc $12 \mathrm{C}$ ) or murine Max protein before addition of the oligonucleotides. Figure 5B demonstrates that the Max antibody disrupted the shift of the EMS oligonucleotide with Max protein. When Myc and Max were incubated with the EMS oligonucleotide, both shifted complexes were disrupted with Max antibody, whereas the Myc antibody only disrupted the slower-migrating complex (Fig. 5B). This confirms that the slower-migrating EMS complex was comprised of Myc/Max heterodimers and the faster-migrating EMS complex contained Max homodimers. The Myc antibody also disrupted the heterodimer complex formed with EFII oligonucleotide. However, the Max antibody caused an additional reproducible supershift with the EFII complex which was not observed with the EMS oligonucleotide (Fig. 5B).

Saturation binding assays, in which a constant amount of protein was titrated with increasing amounts of radiolabeled oligonucleotide containing EMS or EFII sequences, revealed that the amount of probe bound by Myc/Max heterodimers reached saturation at higher levels for the EMS oligonucleotide ( $9 \mathrm{nM}$ bound) compared with the EFII oligonucleotide (5 $\mathrm{nm}$ bound) (data not shown). Therefore, approximately half of the Myc/Max heterodimers capable of binding the EMS DNA can bind to the EFII DNA. Moreover, at the ratios in which the two proteins were mixed (approximately equimolar), there were twofold more Max homodimers than Myc/ Max heterodimers in the mixture capable of binding the EMS DNA (data not shown). This result is comparable with other reports showing that bacterially expressed Max homodimers bound to EMS DNA better than Myc/ Max heterodimers (Kato et al. 1992; Reddy et al. 1992).

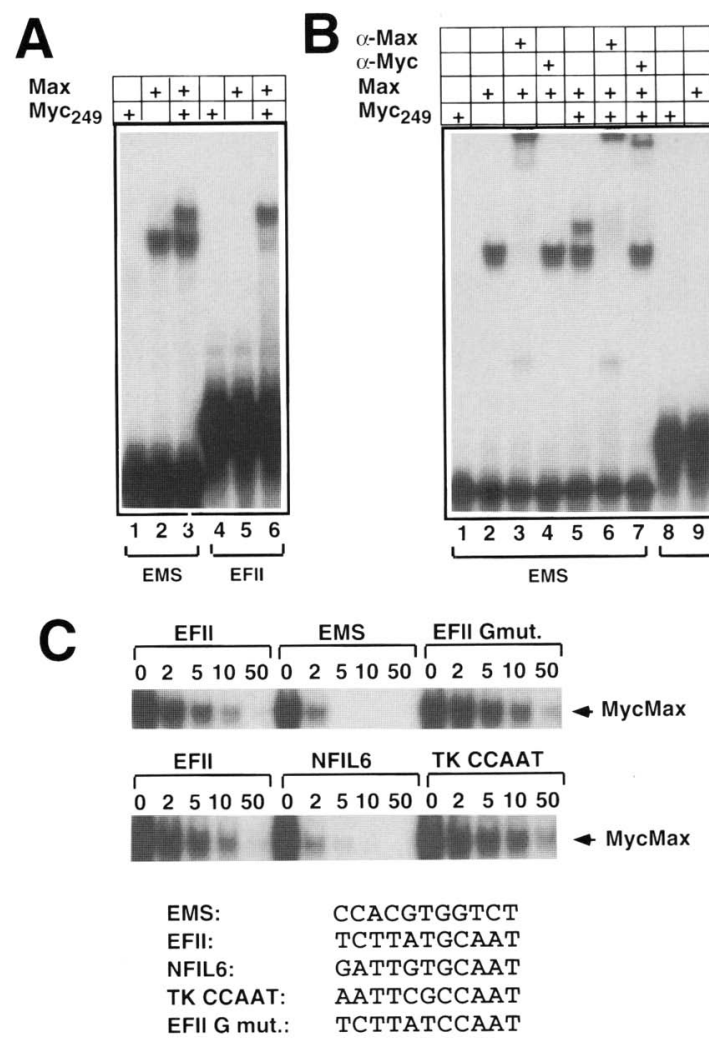

Figure 5. DNA binding of Myc and Max proteins by EMSA. $(A)$ Prior to incubation with DNA, $7.5 \mathrm{ng}$ of Max or $15 \mathrm{ng}$ of Myc249 was preincubated together or individually for $20 \mathrm{~min}$ at $37^{\circ} \mathrm{C}$. The proteins were then mixed with $100 \mathrm{ng}$ of either radiolabeled EMS (lanes 1-3) or EFII (lanes 4-6) DNA. After incubation at room temperature for an additional $20 \mathrm{~min}$, samples were analyzed on $6 \%$ native polyacrylamide gels. $(B)$ DNA-binding assays were performed as in $A$ except that $1 \mu \mathrm{l}($ lanes 3,4$)$ or $2 \mu \mathrm{l}$ (lanes $6,7,11,12$ ) of the indicated antibodies was incubated with the protein samples for $10 \mathrm{~min}$ at room temperature prior to the addition of 0.6 pmole of either radiolabeled EMS DNA (lanes 1-7) or EFII DNA (lanes 8-12). (C) Myc249 and Max proteins were preincubated together as described in $A$ prior to the addition of 0.6 pmole of radiolabeled EFII DNA in the absence or presence of increasing amounts of nonradiolabeled competitor DNAs as indicated. After further incubation at room temperature for $30 \mathrm{~min}$, samples were analyzed by electrophoresis as described in A. Autoradiography of EFII-Myc/Max complexes and the specific C/EBP or E-box motifs present in the competitor oligonucleotides is shown. Complete nucleotide sequences of the 28-bp EMS and 44-bp EFII oligonucleotides are given in Fig. 2A. The nucleotide sequences of NF-IL6 DNA, tk CCAAT DNA, and the 44-bp EFII G-mutant oligonucleotide are described in Materials and methods.

To examine the specificity of Myc/Max heterodimers for the C/EBP-binding site, competition analyses were performed in which Myc/Max binding to radiolabeled EFII probe was competed by oligonucleotides containing various $\mathrm{C} / \mathrm{EBP}$ sites (Fig. $5 \mathrm{C}$ ). These oligonucleotides included one with a C/EBP $\beta$ (NF-IL6)-binding site (Akira et al. 1990), an oligonucleotide containing a suboptimal binding site for C/EBP $\alpha$ first identified in the herpes sim- 
plex virus (HSV) thymidine kinase (tk) promoter that contains a CCAAT sequence rather than a GCAAT motif preferred by C/EBP proteins (Ryden and Beemon 1989), and a mutated EFII oligonucleotide harboring a $\mathrm{G} \rightarrow \mathrm{C}$ substitution. In the cross-competition experiment shown in Figure 5C, the EMS oligonucleotide had a higher affinity (2- to 5-fold) for the Myc/Max heterodimers when compared with EFII DNA. The NF-IL6 (C/EBP $\beta$ ) oligonucleotide also had a higher affinity for Myc/Max heterodimers, approximately equivalent to the EMS sequence. Both of the oligonucleotides with suboptimal C/EBP-binding sites, however, exhibited severalfold lower affinity for the Myc/Max heterodimers relative to the EFII or NF-IL6 sequences.

\section{Differential effects on cell growth by two translational forms of $\mathrm{c}$-Myc protein}

During the generation of COS cell lines stably overexpressing the two forms of the c-Myc protein for the trans-activation assays (Fig. 1) we consistently observed that the cells overexpressing c-Myc 1 appeared to grow slower than the untransfected cells or the cells overexpressing c-Myc 2. To examine these effects further, several different subclones were isolated and analyzed. The expression of the exogenous c-Myc proteins was quantitated by immunoprecipitation using the anti-av-myc $12 \mathrm{C}$ serum. Two subclones overexpressing each form were selected. As shown in Figure 6A, the subclones expressed comparable amounts of c-Myc protein. As shown in Figure 6B, the growth of the two different subclones overexpressing c-Myc 1 was significantly slower than the subclones overexpressing c-Myc 2 and the c-Myc 1-overexpressing cells grew to a significantly lower saturation density. Several other subclones and mixed cul- tures of COS cells overexpressing c-Myc 1 also grew to a lower saturation density.

\section{Discussion}

Two translational forms of c-Myc function differentially

We have found that the c-Myc 1 protein is a potent and specific trans-activator of the EFII enhancer element through the C/EBP-binding site. This trans-activation was independent of the specific cell type or species and occurred either with transient or constitutive expression of the c-Myc 1 protein. Specificity of the EFII-dependent trans-activation was suggested by the observation that the c-Myc 1 protein did not trans-activate the RSV LTR basal promoter sequence (e-), another RSV LTR cis element (EFIII), or a mutant EFII enhancer element (EFII5') 3 ' mutant). In contrast to the dramatic trans-activation by the c-Myc 1 protein, the c-Myc 2 protein either failed to trans-activate the EFII enhancer element or repressed EFII-driven transcription. In addition, the v-Myc proteins appeared to repress transcription significantly through the EFII enhancer element (R. Sears and L. Sealy, unpubl.). Both c-Myc 1 and 2 proteins were competent to trans-activate through the canonical EMS sequence.

Because both of the Myc proteins have the same carboxy-terminal domain, the region sufficient for specific DNA binding and heterodimerization with Max (Blackwood and Eisenman 1991), the opposing effects of these two proteins on EFII-driven transcription are most likely a result of differing amino termini. There are at least two possible explanations for the difference in trans-activation abilities. The short amino-terminal extension of the c-Myc 1 protein (14 amino acids in human and mouse) may contain a trans-activation domain that c-Myc 2

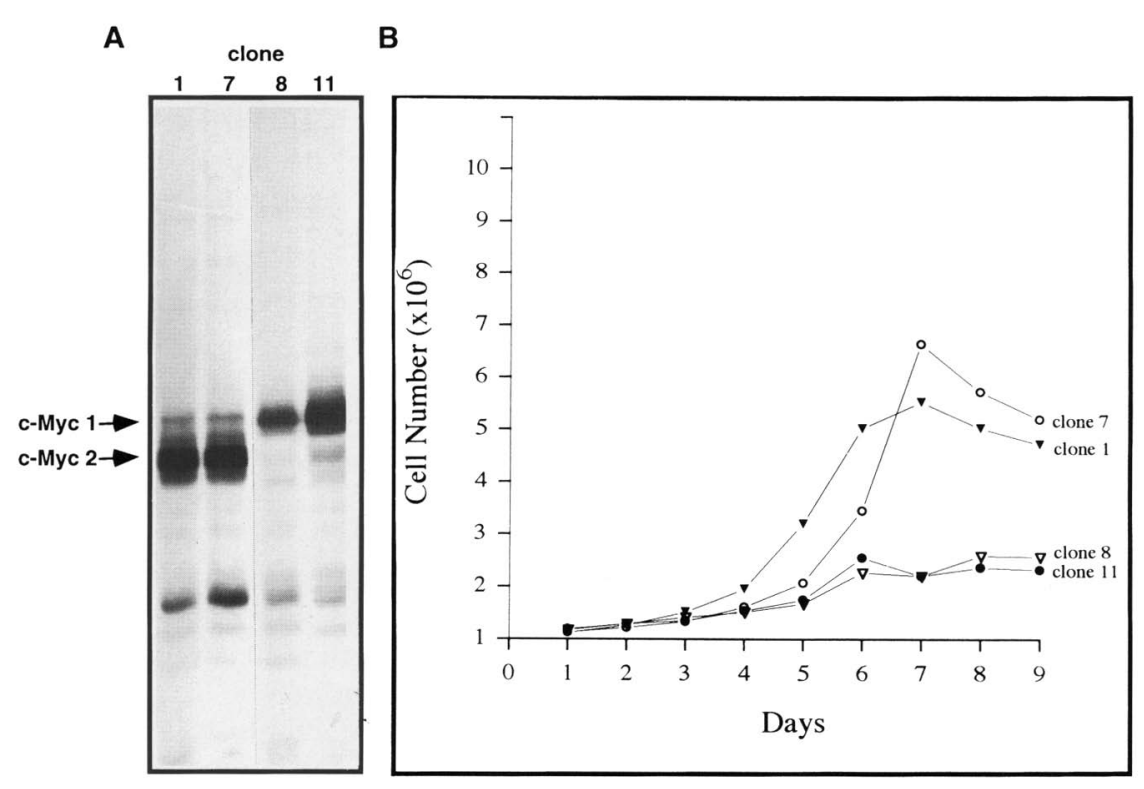

Figure 6. Growth properties of COS cell subclones overexpressing c-Myc 1 and 2 proteins. $(A)$ Numerous subclones were isolated from the COS cell transfection experiments described in Fig. 1. Four representative subclones of COS cells stably overexpressing the CMV-Myc 1 or 2 expression vectors were labeled with $\left[{ }^{35} \mathrm{~S}\right]$ methionine for $20 \mathrm{~min}$, and the cell lysates were equalized for TCA-precipitable counts. The exogenous c-Myc proteins were immunoprecipitated with anti-av-myc $12 \mathrm{C}$ as described in Materials and methods. The low abundant c-Myc protein migrating slightly higher than c-Myc 1 from the CMV-Myc 2 expression vector (subclones 1 and 7) is probably synthesized from an inefficient non-AUG codon adjacent to the CUG start codon. $(B)$ Each subclone was plated in replicate $100-\mathrm{mm}$ dishes at $5 \times 10^{5} /$ dish in DME containing $10 \% \mathrm{CS}$. The number of cells per dish was then determined each day. Each cell count is an average of two dishes. 
lacks. However, this is unlikely because the specific amino acid sequences of the c-Myc 1 amino-terminal extensions are not conserved. Even though the aminoterminal extension of c-Myc 1 is not conserved, both murine and human c-Myc 1 trans-activate the EFII sequence (S. Patel and S. Hann, unpubl.). Therefore, the second, and more likely possibility, is that the aminoterminal extension causes an overall conformational change in the amino-terminal region of the Myc protein containing the trans-activation domain. Evidence supporting such conformational differences comes from the differential recognition of the two c-Myc proteins with an amino-terminal domain antibody. Persson et al. (1984) found that one of their amino-terminal domainspecific antibodies only recognized the c-Myc 2 protein, whereas their other antibodies recognized both proteins. This conformational difference may allow differential contact with the transcriptional machinery depending on the DNA-binding site. The importance of amino-terminal interactions is illustrated by several recent findings. B-Myc protein, which only has an amino-terminal domain, inhibits the function of c-Myc proteins, suggesting that amino-terminal protein-protein interactions are important for c-Myc function (Resar et al. 1993). In additon, the TATA-binding protein (TBP; Hateboer et al. 1993; Maheswaran et al. 1994), and the Rb-like protein, pl07 (Gu et al. 1994), have recently been shown to interact with the amino-terminal domain of c-Myc.

Our finding that the two c-Myc proteins have different transcriptional activities is supported by an earlier report examining the effects of $c-M y c$ overexpression on the E1a-regulated adenovirus promoters, E4 and E2A. Onclercq et al. (1988) demonstrated that the overexpression of the c-Myc proteins strongly trans-activated E4-CAT and E2A-CAT reporter genes. However, a c-myc cDNA expression vector that contained only exons 2 and 3 , and, therefore, could not synthesize c-Myc 1, failed to transactivate these sequences. Therefore, they concluded that the c-Myc 1 protein may be necessary for the trans-activation of these promoters. This idea is especially intriguing because of the similarities between the Myc and Ela proteins. They have been proposed to be functionally similar (Land et al. 1983; Ruley 1983), and the Ela protein exists as two major forms with only the larger one displaying the ability to activate transcription (Velcich and Ziff 1985). Therefore, even though the Ela proteins are not thought to bind directly to DNA and do not share any significant sequence homologies with the Myc proteins, perhaps they can regulate transcription through common DNA elements. The DNA sequence in the E4 adenovirus promoter, which was found necessary for Ela and c-Myc trans-activation (CTATGCAGT), is very similar to the EFII C/EBP-binding site (TTATGCAAT).

\section{A new binding site for $M y c$}

Our results demonstrate that bacterially expressed Myc/ Max heterodimers, but not Max homodimers, can bind to the C/EBP site in vitro. In contrast, both Myc/Max heterodimers and Max homodimers can bind to the EMS sequence in vitro. The differential binding of Max homodimers to these two different sites is supported by the observation that Max overexpression inhibits the transactivation of EMS sequences (Kretzner et al. 1992; Reddy et al. 1992; Amin et al. 1993; Gu et al. 1993), whereas Max overexpression has no effect on the trans-activation of EFII sequences (M. Dixit and S. Hann, unpubl.). We have also confirmed the earlier results of Kato et al. (1992) demonstrating that unphosphorylated Max homodimers preferentially bind to EMS sequences compared with Myc/Max heterodimers.

Our results suggest that the trans-activation of EFII sequences by c-Myc 1 protein involves a direct interaction with DNA rather than through an indirect effect. As discussed above, however, the conformation of the c-Myc 1 trans-activation domain may allow a differential contact with the transcriptional machinery even if c-Myc 1 and 2 both bind DNA comparably. Because both c-Myc proteins trans-activate EMS sequences comparably, a differential effect of c-Myc proteins through a C/EBP-binding site cannot be explained by an increase in transcription of a C/EBP gene or related factor containing EMS regulatory sequences. This idea is also supported by the observation that Max overexpression has no effect on EFII trans-activation while it inhibits EMS trans-activation. Further investigation of the binding of Myc proteins to C/EBP sites is restricted by the limitations of the in vitro binding assays with Myc proteins. Many of the studies examining the DNA-binding properties of c-Myc proteins have used amino-terminally truncated, bacterially expressed fusion proteins (Blackwell et al. 1990; Blackwood et al. 1991; Berberich and Cole 1992; Kato et al. 1992), because full-length Myc proteins expressed in bacteria are largely insoluble. Furthermore, we have been unable to detect protein-DNA complexes containing Myc/Max heterodimers in EMSAs with either EMS or EFII DNA using c-Myc/Max proteins from in vitro translations or from nuclear lysates, whereas in vitro-translated C/EBP proteins bind efficiently to the EFII oligonucleotide in EMSAs (S. Hann and L. Sealy, unpubl.). This inability of nondenatured Myc/Max heterodimers translated from reticulocyte lysates or from nuclear lysates to bind efficiently in vitro has also been observed by several investigators (Berberich and Cole 1992; C. Dang, pers. comm.). A more complete analysis with the native forms of the c-Myc proteins using multiple variations of the sequences will be required to define the optimal DNA binding site and determine the contribution of flanking sequences to the efficiency of c-Myc protein binding.

Because overexpression of Max has no effect on EFII trans-activation and Max homodimers do not bind to EFII sequences, there is also the possibility that another protein, instead of Max, heterodimerizes with c-Myc for optimal binding to the EFII enhancer sequences. There are other reports suggesting that at least some functions of Myc may not require Max protein. One report examined overexpression of a mutated $\mathrm{v}$-Myc protein (Tikhonenko et al. 1993). This predominately cytoplasmic mutated v-Myc protein was still transforming, yet 
the inhibitory Max homodimers (or Mad/Max and Mxi/ Max heterodimers) would have prevailed in the nucleus to block trans-activation of EMS sequences (Tikhonenko et al. 1993). DNA binding, however, was found to be critical for the transforming ability of the mutated v-Myc protein (Tikhonenko et al. 1993). In addition, a recent report demonstrated that the association of Max protein is not required for the ability of c-Myc to repress transcription of the cyclin D1 promoter, but a region of the amino-terminal domain is necessary (Philipp et al. 1994).

\section{Implications for the biological function of $c-M y c$}

The current model on the function of c-Myc suggests that growth stimulatory genes are trans-activated through EMS elements by c-Myc/Max heterodimers. If the amount of c-Myc protein is low, then unphosphorylated Max homodimers (Kretzner et al. 1992; Gu et al. 1993), Mad/Max heterodimers (Ayer et al. 1993), or Mxi/ Max heterodimers (Zervos et al. 1993) inhibit the transactivation. This simple model is complicated by the presence of other factors that bind well to the EMS sequence, such as USF (Gregor et al. 1990), TFE3 (Beckmann et al. 1990), TFEB (Carr and Sharp 1990), and AP-4 (Hu et al. 1990), other noncanonical Myc/Max binding sites (Blackwell et al. 1993), multiple forms of the Max protein (Makela et al. 1992), and the interactions with p107 (Gu et al. 1994), TBP (Hateboer et al. 1993; Maheswaran et al. 1994), TFII-I (Roy et al. 1993), and YY-1 (Shrivastava et al. 1993). As proposed earlier, c-Myc protein also may have several distinct molecular functions besides transcriptional activation, including transcriptional suppression (Philipp et al. 1994) and modulating DNA synthesis directly (Luscher and Eisenman 1990). Our finding that c-Myc 1 and 2 proteins differentially trans-activate through another sequence, the C/EBPbinding site, yet both trans-activate through the EMS sequence, suggests both distinct and overlapping functions for the two proteins.

The regulation of transcription by the Myc proteins through a C/EBP sequence suggests that the overall transcription of genes containing this sequence may be regulated by the relative ratios of the two c-Myc proteins and C/EBP family members in cells. In support of this idea, Freytag and Geddes (1992) have shown that there is opposing regulation of adipogenesis by the C/EBP $\alpha$ and c-Myc 2 proteins. We have also found that the relative levels of the two c-Myc proteins vary greatly in cells depending on the specific growth status (Hann et al. 1992). Growing cells normally have low levels of c-Myc 1 protein compared with c-Myc 2 . However, as cells approach high densities in culture, there is a sustained 5- to 10 -fold increase in the synthesis of $\mathrm{c}-\mathrm{Myc} 1$ protein to levels greater than or equal to the levels of c-Myc 2 synthesis. This dramatic and specific translational activation of c-Myc 1 protein appears to be controlled by the availability of methionine in the growth media (Hann et al. 1992). Therefore, modulating the levels of c-Myc 1 protein may be one of the early cellular responses to control growth in response to limiting nutrients. The existence of a C/EBP/c-Myc 1-trans-activating element in the RSV LTR may ensure vigorous expression of the retrovirus even under poor growth conditions.

Considering the differential, and at times opposing, regulation and transcriptional activities of the two c-Myc proteins, it is likely that they have different biological roles. Previous studies have shown a clear role for c-Myc 2 and v-Myc proteins in growth stimulation and oncogenesis (Cole 1986; Spencer and Groudine 1991). In contrast to the ability of c-Myc 2 and v-Myc proteins to stimulate growth, the loss of c-Myc 1 in most Burkitt's lymphoma cell lines and avian bursal lymphoma cell lines and the induction of high levels of c-Myc 1 in growth-inhibited cells suggest that the c-Myc 1 protein has a growth inhibitory function. Our preliminary growth studies with the different COS cell subclones overexpressing the $\mathrm{c}-\mathrm{Myc}$ proteins demonstrate that c-Myc 1 does have a growth inhibitory effect. Interestingly, overexpression of $\mathrm{C} / \mathrm{EBP} \alpha$ has also been shown to be growth inhibitory (Umek et al. 1991). However, considering that both the c-Myc 1 and 2 proteins trans-activate through EMS sequences, there are some biological functions that may be common to both proteins in some cells. Both proteins are able to cotransform Rat 1 cells with $b c r-a b l$ (Blackwood et al. 1994), and both are able to block differentiation of murine erythroleukemia cells (G. Spotts and S. Hann, unpubl.). Perhaps when there is a disruption of c-Myc 1 protein synthesis as a result of a genetic mutation or rearrangement, as in human Burkitt's lymphomas and avian bursal lymphomas, specific cells lose a growth-inhibiting response to limiting nutrients which contributes to tumorigenicity.

\section{Materials and methods}

\section{Cell lines}

COS-1 cells were obtained from Stephen Brandt and Tom Daniel (Vanderbilt University, Nashville, TN). HeLa cells were obtained from Roland Stein (Vanderbilt University). The mink epithelial cell line CCL64 was obtained from Ed Leof (Mayo Clinic, Rochester, MN). The human lung fibroblast cell lines and 75 were obtained from the ATCC. COS-1 cells stably overexpressing the c-Myc proteins were generated by electroporation of $10 \mu \mathrm{g}$ of CMV-Myc 1 or CMV-Myc 2 expression vectors and selected in growth medium containing $400 \mu \mathrm{g}$ of $\mathrm{G} 418$ after $48 \mathrm{hr}$.

\section{Plasmids and vectors}

The construction of the plasmids SRA-CAT, e-CAT, $[\text { EFII }]_{1}{ }^{-}$ CAT (p[EFII] $1+\mathrm{CAT}),[\text { EFII }]_{6} \mathrm{CAT}$ (p[EFII] $\left.6+\mathrm{CAT}\right)_{t}$ [EFII5' $3^{\prime}$ mutant $)_{2}$ CAT $\left(\mathrm{p}\left[\right.\right.$ EFII3' $\left.\left./ 5^{\prime}\right] 2+\mathrm{CAT}\right)$, and [EFI5' $]_{4}$ CAT4 $(\mathrm{p}[\mathrm{E}-$ FII5']4-CAT4) have been described previously (Sears and Sealy 1992). The construction of the [EFIII $]_{5}$ CAT plasmid has been described in Boulden and Sealy (1992). Site-directed mutagenesis of the murine myc cDNA lobtained from Michael Cole, Princeton, NJ) was performed by Samuel Pfaff (Vanderbilt University) using the Amersham kit. The Xhol restriction fragments of the mutated murine c-myc cDNAs were subcloned into the pGem3 plasmid (Promega) and then HindIII-XbaI restriction fragments were subcloned into the CMV expression 
vector, $\mathrm{pRc} / \mathrm{CMV}$ (Invitrogen). The SV40- $\beta$-galactosidase expression vector was obtained from Mark Magnuson (Vanderbilt University|. The pbsCAT riboprobe plasmid was constructed by Amy Boulden and contains an EcoRI fragment from pBLCAT4 (Buscher et al. 1988) with tkCAT gene sequences from -79 to +242 subcloned into the EcoRI site of the Bluescript|+| plasmid containing a $\mathrm{T} 7$ promoter. The bacterial expression vectors, His-Max and His-Myc249, were obtained from Michael Cole and were described in Berberich and Cole (1992). The complete nucleotide sequences of NF-IL6 DNA, a 32-bp oligonucleotide containing sequences -163 to -138 of the human IL- 6 gene promoter, and tk CCAAT DNA, a 30-bp oligonucleotide containing sequences -68 to -97 of the HSV tk gene promoter, are given in Boulden and Sealy (1992) and Faber and Sealy (1990), respectively. Nucleotide sequence of the 44-bp EFII G-mutant oligonucleotide is CCGAGAATGTAGTCTTATCCAATACTCTTGTAGTCTTCCAACAC CTTACATCAGAATAGGTTATGAGAACATCAGAAGGTTGTGGGCT.

\section{DNA oligomers and EMSA}

The EFII oligonucleotide was synthesized (DRTC DNA core, Vanderbilt University) and purified as described by Boulden and Sealy (1990). The EMS oligonucleotide was synthesized and purified by Bio-synthesis, Inc. (Lewisville, TX). The proteins were purified as described by Qiagen (Chatsworth, CA) with final dialysis in $6.25 \mathrm{~mm}$ MES [2-(4-morpholino)-ethane sulfonic acid] at $\mathrm{pH} 8,5 \%$ glycerol, and $1 \mathrm{~mm}$ dithiothreitol. Double-stranded synthetic EMS and EFII oligonucleotides were radiolabeled by incubation with $\left[\gamma^{32}\right.$ P]ATP and T4 polynucleotide kinase and then purified by gel electrophoresis. Prior to incubation with DNA, Max and Myc249 were preincubated together or individually for $20 \mathrm{~min}$ at $37^{\circ} \mathrm{C}$ in a buffer containing $7 \mathrm{mM}$ HEPES at $\mathrm{pH} 8,1.8 \mathrm{~mm}$ MES at $\mathrm{pH} 8,2.1 \mathrm{~mm} \mathrm{MgCl}_{2}, 0.7 \mathrm{~mm}$ EDTA at $\mathrm{pH}$ $8,0.3 \mathrm{~mm}$ dithiothreitol, $35 \mathrm{mM} \mathrm{NaCl}$, and $36.5 \%$ glycerol. The proteins were then mixed with DNA in a buffer containing 12 mM HEPES at $\mathrm{pH} 8,2.5 \mathrm{~mm}$ Tris at $\mathrm{pH} 8,0.5 \mathrm{~mm}$ MES at $\mathrm{pH} 8$, $2.7 \mathrm{mM} \mathrm{MgCl}_{2}, 0.7 \mathrm{mM}$ EDTA, $2.5 \mathrm{~mm} \beta$-mercaptoethanol, $0.075 \mathrm{~mm}$ dithiothreitol, $40 \mathrm{mM} \mathrm{NaCl}, 16 \%$ glycerol, and $0.035 \%$ NP- 40 . After incubation at room temperature for an additional $20 \mathrm{~min}$, samples were analyzed on a native $6 \%$ polyacrylamide gel containing TGE (25 mM Tris at pH 8.5, $190 \mathrm{~mm}$ glycine, $1 \mathrm{mM}$ EDTA) buffer. Antibodies ( 1 or $2 \mu \mathrm{l}$ ) were incubated with the protein for $10 \mathrm{~min}$ at room temperature before addition of the oligonucleotide.

\section{In vitro transcription and in vitro translation}

The CMV-Myc vectors were linearized with $X b a I$, and RNA was prepared using the Gemini II kit (Promega). The RNA was then translated using the rabbit reticulocyte translation kit (Promega).

\section{Antisera}

The affinity-purified rabbit avian-specific c-myc peptide antibody (anti-av-myc 12C) was generated as described previously (Hann et al. 1983) and was used to detect the exogenous modified murine Myc proteins expressed by the CMV-Myc vectors. The affinity-purified rabbit murine-specific c-myc peptide antibody (anti-Mu-myc 12C) was generated as described in Spotts and Hann (1990). The Max antiserum was generated by inoculating a New Zealand white rabbit with complete Freund's adjuvant containing $500 \mu \mathrm{g}$ of purified bacterially expressed murine His-Max protein.

\section{Immunoprecipitation}

Cells were labeled and immunoprecipitations were performed as described previously in Spotts and Hann (1990). Briefly, $1 \times 10^{7}$ cells were labeled with $350 \mu \mathrm{Ci}$ of $\left[{ }^{35} \mathrm{~S}\right]$ methionine in 1 $\mathrm{ml}$ of methionine-free medium for $20 \mathrm{~min}$. Cells were solubilized in Ab buffer (Hann et al. 1983) and disrupted by sonication. The amount of $\left[{ }^{35} \mathrm{~S}\right]$ methionine incorporated into cellular proteins was determined by precipitation onto filters with $10 \%$ trichloroacetic acid (TCA). Equivalent amounts of TCA-precipitable counts from each cellular lysate were adjusted to equal volumes with $\mathrm{Ab}$ buffer, precleared with Staphylococcus aureus membranes (Immunoprecipitin, BRL) and clarified by centrifugation. The appropriate antiserum was incubated with the clarified lysates overnight at $4^{\circ} \mathrm{C}$, and the immune complexes were precipitated with Immunoprecipitin for $30 \mathrm{~min}$. After three washes in RIPA buffer, the complexes were disrupted by incubation in Laemmli sample buffer for $3 \mathrm{~min}$ at $95^{\circ} \mathrm{C}$. Samples were subjected to SDS-PAGE $\{10 \%$ acrylamide $\}$, and fluorography was performed as described by Skinner and Griswold (1983). Molecular mass standards consisted of phosphorylase B $(97.4$ $\mathrm{kD}$ ), bovine serum albumin $(68.4 \mathrm{kD})$, and ovalbumin (43 kD).

\section{Transient transfections and enzymatic assays}

Transfections were performed by the calcium phosphate coprecipitation technique as described by Graham and Van der Eb (1973). Cells were plated onto $100-\mathrm{mm}$ dishes at $1 \times 10^{6}$ cells/ dish in Dulbecco's modified Eagle medium (DMEM) containing $10 \%$ calf serum (CS) (Colorado Serum Co.) $24 \mathrm{hr}$ prior to transfection and were $\sim 80 \%$ confluent when transfected. The quantities and type of DNA used are described in the figure legends. Cells were exposed to the $\mathrm{CaPO}_{4}-\mathrm{DNA}$ precipitate for $\sim 4 \mathrm{hr}$, at which time they were washed twice with PBS and refed fresh DME plus $10 \% \mathrm{CS}$. After an additional $48 \mathrm{hr}$, lysates were prepared from the transfected cells by sonication in $0.25 \mathrm{M}$ Tris$\mathrm{HCl}$ at $\mathrm{pH} 8$ and clarified by centrifugation. Units of $\beta$-galactosidase activity in the cell extracts were determined as described in Norton and Coffin (1985), and the amount of extracts to be used for CAT assays was determined by equalizing for units of $\beta$-galactosidase to normalize for transfection efficiencies. CAT assays were performed by the procedure of Gorman et al. (1982). CAT activity for each sample was calculated by cutting out the acetylated and unreacted forms of $\left[{ }^{14} \mathrm{C} \mid \mathrm{chloram}\right.$ phenicol, quantitating the radioactivity by liquid scintillation counting, and then determining the percent acetylation.

\section{Acknowledgments}

We thank Michael Cole for the kind gifts of murine c-myc cDNA, pBKSmax cDNA, and the His-Myc249 and His-Max bacterial expression vectors. We also thank John Cleveland, Gail Cornwall, Steven Hanks, Mary Ann Thompson, Gerald Spotts, and Earl Ruley for critical review of this manuscript and Suzanne Justis for assistance with the photography and antibody preparation. Finally, we thank Roger Chalkley for helpful suggestions and for encouraging us to remember the second law of thermodynamics. This work was supported by U.S. Public Health Service grants CA-47399 and CA-48799 to S.R.H. and GM39326 to L.S.

The publication costs of this article were defrayed in part by payment of page charges. This article must therefore be hereby marked "advertisement" in accordance with 18 USC section 1734 solely to indicate this fact. 


\section{References}

Akira, S., H. Isshiki, T. Sugita, O. Tanabe, S. Kinoshita, Y. Nishio, T. Nakajima, T. Hirano, and T. Kishimoto. 1990. A nuclear factor for IL-6 expression (NF-IL6) is a member of a C/EBP family. EMBO I. 9: 1897-1906.

Amati, B., M.W. Brooks, N. Levy, T. Littlewood, G. Evan, and H. Land. 1993. Oncogenic activity of the c-Myc protein requires dimerization with Max. Cell 72: 233-245.

Amin, C., A. Wagner, and N. Hay. 1993. Sequence-specific trans-activation by myc and repression by max. Mol. Biol. Cell. 13: 383-390.

Askew, D., R. Ashmun, B. Simmons, and J. Cleveland. 1991. Constitutive c-myc expression in an IL-3-dependent myeloid cell line suppresses cell cycle arrest and apoptosis. Oncogene 6: 1915-1922.

Ayer, D.E., L. Kretzner, and R.N. Eisenman. 1993. Mad: A heterodimeric partner for Max that antagonizes myc transcriptional activity. Cell 72: 211-222.

Beckmann, H.L., L.K. Su, and T. Kadesch. 1990. TFE3: A helixloop-helix protein that activates transcription through the immunoglobulin enhancer $\mu \mathrm{E} 3$ motif. Genes \& Dev. 4: 167179.

Bello-Fernandez, C., G. Packham, and I. Cleveland. 1993. The ornithine decarboxylase gene is a transcriptional target of c-Myc. Proc. Natl. Acad. Sci. 90: 7804-7808.

Benvenisty, N., A. Leder, A. Kuo, and P. Leder. 1992. An embryonically expressed gene is a target for c-Myc regulation via the c-Myc-binding sequence. Genes \& Dev. 6: 25132523.

Berberich, S.J. and M.D. Cole. 1992. Casein kinase II inhibits the DNA-binding activity of Max homodimers but not Myc/ Max heterodimers. Genes \& Dev. 6: 166-176.

Blackwell, T.K., L. Kretzner, E.M. Blackwood, R.N. Eisenman, and H. Weintraub. 1990. Sequence-specific DNA binding by the c-myc protein. Science 250: 1149-1151.

Blackwell, T.K., J. Huang, A. Ma, L. Kretzner, F. Alt, R.N. Eisenman, and H. Weintraub. 1993. Binding of Myc proteins to canonical and non-canonical DNA sequences. Mol. Cell. Biol. 13: 5216-5224.

Blackwood, E.M. and R.N. Eisenman. 1991. Max: A helix-loophelix zipper protein that forms a sequence-specific DNAbinding complex with myc. Science 251: 1211-1217.

Blackwood, E., T. Lugo, L. Kretzner, M. King, A. Street, O. Witte, and R. Eisenman. 1994. Functional analysis of the AUG- and CUG-initiated forms of the c-Myc protein. Mol. Biol. Cell. 5: 597-609.

Boulden, A. and L. Sealy. 1990. Identification of a third protein factor which binds to the Rous sarcoma virus LTR enhancer: Possible homology with the serum response factor. Virology 174: 204-216.

1992. Maximal serum stimulation of the c-fos SRE requires both the serum response factor and a novel binding factor, SRE BP. Mol. Cell. Biol. 12: 4769-4783.

Bowers, W.J. and A. Ruddell. 1993. al/EBP: a leucine zipper protein that binds CCAAT/enhancer elements in the avian leukosis virus long terminal repeat enhancer. I. Virol. 66: $6578-6586$.

Buscher, M., H.J. Rahmsdorf, M. Litfin, M. Karin, and P. Herrlich. 1988. Activation of the $c$-fos gene by UV and phorbol ester: Different signal pathways converge to the same enhancer element. Oncogene 3: 301-311.

Cao, Z., R. Umek, and S. McKnight. 1991. Regulated expression of three C/EBP isoforms during adipose conversion of 3T3L1 cells. Genes \& Dev. 5: 1538-1552.

Carr, C.S. and P.A. Sharp. 1990. A helix-loop-helix protein re- lated to immunoglobulin E box-binding proteins. Mol. Cell. Biol. 10: $4384-4388$.

Cole, M.D. 1986. The myc oncogene: Its role in transformation and differentiation. Annu. Rev. Genet. 20: 361-384.

Dang, C.V., M. McGuire, M. Buckmire, and W.M.F. Lee. 1989. Involvement of the "leucine zipper" region in the oligomerization and transforming activity of human c-myc protein. Nature 337: 664-666.

Davis, R.L., P. Cheng, A.B. Lassar, and H. Weintraub. 1990. The MyoD DNA binding domain contains a recognition code for muscle-specific gene activation. Cell 60: 733-746.

Donahue, T.F., A.M. Cigan, E.K. Pabich, and B.C. Valavicius. 1988. Mutations at a $\mathrm{Zn}$ (II) finger motif in the yeast eIF-2 $\beta$ gene alter ribosomal start-site selection during the scanning process. Cell 54: 621-632.

Dosaka-Akita, H., R.K. Rosenberg, J.D. Minna, and M.J. Birrer. 1991. A complex pattern of translational initiation and phosphorylation in L-Myc proteins. Oncogene 6: 371-378.

Evan, G., A.H. Wyllie, C. Gilbert, T. Littlewood, H. Land, M. Brooks, C. Waters, L. Penn, and D. Hancock. 1992. Induction of apoptosis in fibroblasts by c-myc protein. Cell 69: 119128.

Faber, M. and L. Sealy. 1990. Rous sarcoma virus enhancer factor I is a ubiquitous CCAAT transcription factor highly related to CBF and NF-Y. J. Biol. Chem. 265: 22243-22254.

Freytag, S.O. and T.J. Geddes. 1992. Reciprocal regulation of adipogenesis by myc and C/EBP $\alpha$. Science 256: 379-382.

Gorman, C.M., L.F. Moffat, and B.H. Howard. 1982. Recombinant genomes which express chloramphenicol acetyltransferase in mammalian cells. Mol. Cell. Biol. 2: 1044-1051.

Graham, F.L. and A.J. Van der Eb. 1973. A new technique for the assay of infectivity of the human adenovirus 5 DNA. Virology 52: 456-467.

Gregor, P.D., M. Sawadogo, and R.G. Roeder. 1990. The adenovirus major late transcription factor USF is a member of the helix-loop-helix group of regulatory and binds to DNA as a dimer. Genes \& Dev. 4: 1730-1740.

Gu, W., K. Cechova, V. Tassi, and R. Dalla-Favera. 1993. Opposite regulation of gene transcription and cell proliferation by c-Myc and Max. Proc. Natl. Acad. Sci. 90: 2935-2939.

Gu, W., K. Bhatia, I. Magrath, C. Dang, and R. Dalla-Favera. 1994. Binding and suppression of the Myc transcriptional activation domain by p107. Science 264: 251-254.

Halazonetis, T.D. and A.N. Kandil. 1991. Determination of the c-myc DNA-binding site. Proc. Natl. Acad. Sci. 88: 61626166.

Hann, S.R. and R.N. Eisenman. 1984. Proteins encoded by the human c-myc oncogene: Differential expression in neoplastic cells. Mol. Cell. Biol. 4: 2486-2497.

Hann, S.R., H.D. Abrams, L.R. Rohrschneider, and R.N. Eisenman. 1983. Proteins encoded by the v-myc and c-myc oncogenes: Identification and localization in acute leukemia virus transformants and bursal lymphoma cell lines. Cell 34: 789-798.

Hann, S.R., M.W. King, D.L. Bentley, C.W. Anderson, and R.N. Eisenman. 1988. A non-AUG translational initiation in c-myc exon 1 generates an $\mathrm{N}$-terminally distinct protein whose synthesis is disrupted in Burkitt's lymphomas. Cell 34: 185-195.

Hann, S.R., K. Sloan-Brown, and G. Spotts. 1992. Translational activation of the non-AUG-initiated c-myc l protein at high cell densities due to methionine deprivation. Genes \& Dev. 6: 1229-1240.

Hateboer, G., H. Timmers, A. Rustgi, M. Billaud, L. Van 'T Veer, and R. Bernards. 1993. TATA-binding protein and the retinoblastoma gene product bind to overlapping epitopes on 
c-Myc and adenovirus Ela protein. Proc. Natl. Acad. Sci. 90: 8489-8493.

Hu, Y.F., B. Luscher, A. Admon, N. Mermod, and R. Tjian. 1990. Transcription factor AP-4 contains multiple dimerization domains that regulate dimer specificity. Genes \& Dev. 4: 1741-1752.

Kato, G.J., J. Barrett, M. Villa-Garcia, and C.V. Dang. 1990. An amino-terminal c-myc domain required for neoplastic transformation activates transcription. Mol. Cell. Biol. 10: 5914 5920.

Kato, G.J., W.M.F. Lee, L. Chen, and C.V. Dang. 1992. Max: Functional domains and interaction with c-myc. Genes \& Dev. 6: 81-92.

Kretzner, L., E.M. Blackwood, and R.E. Eisenman. 1992. Myc and Max proteins possess distinct transcriptional activities. Nature 359: 426-429.

Land, H., L.F. Parada, and R. Weinberg. 1983. Tumorigenic conversion of primary embryo fibroblasts requires at least two oncogenes. Nature 304: 596-602.

Littlewood, T., B. Amati, H. Land, and G. Evan. 1992. Max and c-Myc/Max DNA-binding activities in cell extracts. Oncogene 7: 1783-1792.

Luscher, B. and R.N. Eisenman. 1990. New light on Myc and Myb. Part I. Myc. Genes \& Dev. 4: 2025-2035.

Maheswaran, S., H. Lee, and G. Sonenshein. 1994. Intracellular association of the protein product of the c-myc oncogene with the TATA-binding protein. Mol. Cell. Biol. 14: 11471152.

Makela, T.P., P.J. Koskinen, I. Vastrik, and K. Alitalo. 1992. Alternative forms of Max as enhancers or suppressors of Myc-Ras cotransformation. Science 256: 373-376.

Norton, P.A. and J.M. Coffin. 1985. Bacterial $\beta$-galactosidase as a marker of Rous sarcoma virus gene expression and replication. Mol. Cell. Biol. 5: 281-290.

Onclercq, R., P. Gilardi, A. Lavenu, and C. Cremisi. 1988. c-myc products trans-activate the adenovirus E4 promoter in EC stem cells by using the same target sequence as E1A products. J. Virol. 62: 4533-4537.

Peabody, D.S. 1989. Translation initiation at non-AUG triplets in mammalian cells. $J$. Biol. Chem. 264: 5031-5035.

Persson, H., L. Hennighausen, R. Taub, W. DeGrado, and P. Leder. 1984. Antibodies to human c-myc gene product: Evidence of an evolutionarily conserved protein induced during cell proliferation. Science 225: 687-693.

Philipp, A., A. Schneider, I. Vasrik, K. Finke, Y. Xiong, D. Beach, K. Alitalo, and M. Eilers. 1994. Repression of cyclin D1: a novel function of myc. Mol. Cell. Biol. 14: 4032-4043.

Prendergast, G.C. and E.B. Ziff. 1991. Methylation-sensitive sequence-specific DNA binding by the c-myc basic region. Science 251: 186-189.

Prendergast, G.C., D. Lawe, and E.B. Ziff. 1991. Association of Myn, the murine homologue of Max, with c-myc stimulates methylation-sensitive DNA binding and ras cotransformation. Cell 65: 395-407.

Ramsay, G., L. Stanton, M. Schwab, and J.M. Bishop. 1986. The human proto-oncogene $\mathrm{N}$-myc encodes nuclear proteins that bind DNA. Mol. Cell. Biol. 6: 4450-4457.

Reddy, C., P. Dasgupta, P. Saikumar, H. Dudek, F. Rauscher, and E. Reddy. 1992. Mutational analysis of Max: Role of basic, helix-loop-helix/leucine zipper domains in DNA binding, dimerization and regulation of Myc-mediated transcriptional activation. Oncogene 7: 2085-2092.

Reisman, D., N.B. Elkind, B. Roy, J. Beamon, and V. Rotter. 1993. c-Myc transactivates the p53 promoter through a requirted CACGTG motif. Cell Growth Differ. 4: 57-65.

Resar, L.M., C. Dolde, J.F. Barrett, and C.V. Dang. 1993. B-Myc inhibits neoplastic transformation and transcriptional activation by c-Myc. Mol. Cell. Biol. 13: 1130-1136.

Roman, C., J.S. Platero, J. Shuman, and K. Calame. 1990. Ig/ EBP-1: A ubiquitously expressed immunoglobulin enhancer binding protein that is similar to C/EBP and heterodimerizes with C/EBP. Genes \& Dev. 4: 1404-1415.

Roy, A., C. Carruthers, T. Gutjahr, and R.G. Roeder. 1993. Direct role for Myc in transcription initiation mediated by interactions with TFII-I. Nature 365: 359-361.

Ruly, H.E. 1983. Adenovirus early region la enables viral and transforming genes to transform primary cells in culture. Nature 304: 602-606.

Ryden, T.A. and K. Beemon. 1989. Avian retroviral long terminal repeats bind CCAAT/enhancer-binding protein. Mol. Cell. Biol. 9: 1155-1164.

Sealy, L. and R. Chalkley. 1987. At least two nuclear proteins bind specifically to the Rous sarcoma virus long terminal repeat enhancer. Mol. Cell. Biol. 7: 787-798.

Sears, R.C. and L. Sealy. 1992. Characterization of nuclear proteins that bind the EFII enhancer sequence in the Rous sarcoma virus LTR. J. Virol. 66: 6338-6352.

1994. Multiple forms of C/EBP $\beta$ bind EFII enhancer sequence in the Rous sarcoma virus long terminal repeat. Mol. Cell. Biol. 14: 4855-4871.

Shrivastava, A., S. Saleque, G.V. Kalpana, S. Artandi, S.P. Goff, and K. Calame. 1993. Inhibition of transcriptional regulator Yin-Yang-1 association with c-Myc. Science 262: 2479624804.

Skinner, M.K. and M.D. Griswold. 1983. Fluorographic detection of radioactivity with 2,5-diphenlyoxazole in acetic acid and its comparison with existing procedures. Biochem. J. 209: 281-284.

Spencer, C.A. and M. Groudine. 1991 Control of c-myc regulation in normal and neoplastic cells. Adv. Cancer Res. 56: 148.

Spotts, G.D. and S.R. Hann. 1990. Enhanced translation and increased turnover of $c$-myc proteins occur during differentiation of murine erythroleukemia cells. Mol. Cell. Biol. 10: 3952-3964.

Stone, J., T. DeLange, G. Ramsay, E. Jakobovits, J.M. Bishop, H. Varmus, and W. Lee. 1987. Definition of regions of human $\mathrm{c}-\mathrm{myc}$ that are involved in transformation and nuclear localization. Mol. Cell. Biol. 7: 1697-1709.

Tikhonenko, A., A. Hartman, and M. Linial. 1993. Overproduction of $\mathrm{v}-\mathrm{Myc}$ in the nucleus and its excess over Max are not required for avian fibroblast transformation. Mol. Cell. Biol. 13: $3623-3631$.

Umek, R.M., A.D. Friedman, and S.L. McKnight. 1991. CCAAT/enhancer binding protein: a component of a differentiation switch. Science 251: 288-292.

Velcich, A. and E. Ziff. 1985. Adenovirus Ela proteins repress transcription from the SV40 early promoter. Cell 40: 705716.

Voronova, A. and D. Baltimore. 1990. Mutations that disrupt DNA binding and dimer formation in the E47 helix-loophelix protein map to distinct domains. Proc. Natl. Acad. Sci. 87: $4722-4726$.

Wegner, M., Z. Cao, and M.G. Rosenfeld. 1992. Calcium-regulated phosphorylation within the leucine zipper of C/EBP $\beta$. Science 256: 370-373.

Zervos, A.S., J. Gyuris, and R. Brent. 1993. Mxil, a protein that specifically interacts with Max to bind Myc/Max recognition sites. Cell 72: 223-232. 


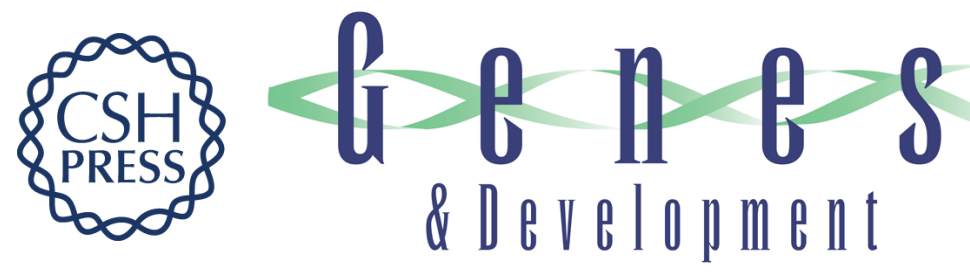

\section{The alternatively initiated c-Myc proteins differentially regulate transcription through a noncanonical DNA-binding site.}

S R Hann, M Dixit, R C Sears, et al.

Genes Dev. 1994, 8:

Access the most recent version at doi:10.1101/gad.8.20.2441

References This article cites 76 articles, 48 of which can be accessed free at:

http://genesdev.cshlp.org/content/8/20/2441.full.html\#ref-list-1

License

Email Alerting

Service

Receive free email alerts when new articles cite this article - sign up in the box at the top right corner of the article or click here.

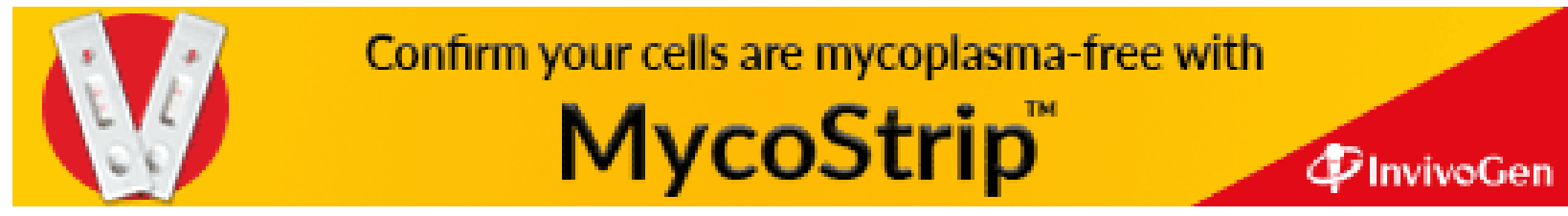

